\title{
PENGARUH PANJANG PENYALURAN TERHADAP KUAT CABUT TULANGAN BAJA
}

\author{
Arusmalem Ginting, Tri Wahyu Purnomo \\ Jurusan Teknik Sipil, Fakultas Teknik, Universitas Janabadra \\ Jl. Tentara Rakyat Mataram No. 55-57, Yogyakarta, email : agintm@yahoo.com
}

\begin{abstract}
ABSTRAK
Salah satu persyaratan dalam perancangan beton bertulang yang harus diperhatikan adalah panjang penyaluran tulangan. Panjang penyaluran adalah panjang penambatan yang diperlukan untuk mengembangkan tegangan luluh pada tulangan yang merupakan fungsi dari tegangan luluh baja, diameter tulangan, dan tegangan lekat. Panjang penyaluran menentukan tahanan terhadap tergelincirnya tulangan. Tujuan dari penelitian ini adalah untuk mengetahui pengaruh panjang penyaluran terhadap kuat cabut tulangan baja dari beton. Pada penelitian ini digunakan 12 buah benda uji kuat cabut yang berupa silinder beton dengan diameter $150 \mathrm{~mm}$ dan tinggi $300 \mathrm{~mm}$. Pada bagian tengah silinder ditanam tulangan ulir berdiameter $16,4 \mathrm{~mm}$ dengan panjang penyaluran tulangan $\left(l_{d}\right)$ dibuat bervariasi. Variasi panjang penyaluran yang digunakan adalah: $50,100,150$, 200, 250, dan $300 \mathrm{~mm}$. Jumlah benda uji untuk masing-masing variasi panjang penyaluran sebanyak dua buah. Pengujian kuat lekat dilakukan dengan cara menempatkan silinder beton pada loading frame yang dilengkapi dengan hydraulic jack dan load cells, batang tulangan yang tertanam pada silinder ditarik sampai tercabut. Hasil pengujian yang didapat berupa data beban cabut maksimum. Dari hasil penelitian ini didapat kuat tekan rata-rata silinder beton sebesar 27,63 MPa. Tegangan luluh rata-rata tulangan D16,4 sebesar 483,66 MPa. Peningkatan panjang penyaluran dari 50, 100, 150, 200, 250, hingga 300 mm meningkatan kemampuan benda uji untuk mendukung gaya cabut. Kuat cabut meningkat dan berbanding lurus sampai panjang penyaluran tertentu. Kegagalan pada uji cabut tulangan dapat berupa tulangan tercabut beton utuh atau tulangan tercabut beton terbelah.
\end{abstract}

Kata kunci : panjang penyaluran, kuat cabut.

\begin{abstract}
One of the factors that must to be calculating in the design of the reinforced concrete was development length of reinforcement. Development length is anchor length required to develop yield stress of reinforcing bar which is a function of yield strength of the reinforcement, diameter of the reinforcement bar, and bond stress. Development length determined resistance against slippage of reinforcement. The aim of this research was to know the influence of development length against pullout strength of reinforcement from the concrete. In this research was used 12 samples of the pullout used the concrete cylinder $150 \times 300 \mathrm{~mm}$. A single deformed bar diameter $16.4 \mathrm{~mm}$ was embedded in a concrete cylinder with development length be varied. The development length that was used: 50, 100, 150, 200, 250, and $300 \mathrm{~mm}$. Each variation development length was used two samples. The testing of pullout in loading frame that was equipped with hydraulic jack and load cells, then reinforcing bar was embedded in a concrete cylinder pullout. Results of the testing that was maximum pullout strength. The results of this research was gotten average compression strength of concrete cylinder was 27.63 MPa. Average yield stress of deformed steel bar D16.4 was 483.66 MPa. Increased the development length from $50 \mathrm{~mm}$ to $300 \mathrm{~mm}$ will increase the pullout strength. Pullout strength increased linearly until certain development length. There were two types pullout failure that is reinforcing bar was pullout and the concrete was not split or reinforcing bar was pullout and the concrete was split.
\end{abstract}

Key words: development length, pullout strength. 


\section{PENDAHULUAN}

Beton banyak digunakan sebagai bahan bangunan karena harganya relatif murah, kuat tekannya tinggi, dapat dibuat sesuai dengan bentuk dan ukuran yang diinginkan, dapat dikombinasikan dengan baja tulangan, dan masih banyak lagi kelebihan-kelebihan yang lain. Beton mempunyai kekuatan yang besar dalam menahan gaya tekan (compression), tetapi lemah dalam menahan gaya tarik. Bagian beton yang menahan gaya tarik diperkuat atau digantikan oleh baja tulangan.

Salah satu dasar anggapan yang digunakan dalam perencanaan dan analisis struktur beton bertulang adalah lekatan batang tulangan baja dengan beton yang mengelilinginya berlangsung sempurna tanpa terjadi penggelinciran atau pergeseran. Berdasarkan atas anggapan tersebut maka pada waktu komponen struktur beton bertulang bekerja menahan beban akan timbul tegangan lekat pada permukaan singgung antara batang tulangan dengan beton (Dipohusodo, 1994).

Tulangan polos dapat terlepas dari beton karena terbelah di arah memanjang bila adhesi atau perlawanan gesek cukup tinggi, atau dapat terlepas keluar dengan meninggalkan lobang bulat di dalam beton untuk adhesi dan tahanan gesek yang rendah. Batang tulangan berprofil direncanakan untuk merubah pola perilaku dan memperkecil andalan atas gesekan dan adhesi, dan lebih mengandalkan tahanan dari gerigi terhadap beton. Keruntuhan lekatan (bond failure) tulangan berprofil di dalam beton berbobot normal hampir selalu merupakan keruntuhan akibat terbelahnya beton. Pada pola keruntuhan pembelahan ini, beton terbelah menjadi dua atau tiga bagian karena aksi baji (wedging) dari gerigi terhadap beton (Wang, 1993).

Salah satu persyaratan dalam perancangan beton bertulang yang harus diperhatikan adalah panjang penyaluran tulangan. Menurut Dipohusodo (1994), panjang penyaluran adalah panjang penambatan yang diperlukan untuk mengembangkan tegangan luluh pada tulangan yang merupakan fungsi dari tegangan luluh baja $\left(f_{y}\right)$, diameter tulangan, dan tegangan lekat. Panjang penyaluran menentukan tahanan terhadap tergelincirnya tulangan.

Tujuan dari penelitian ini adalah untuk mengetahui pengaruh panjang penyaluran terhadap kuat cabut tulangan baja dengan beton.

\section{TINJAUAN LITERATUR}

Menurut Nawy (1998) kuat lekat antara tulangan dan beton merupakan hasil dari berbagai parameter, seperti lekatan antara beton dengan permukaan tulangan baja dan tekanan beton terhadap tulangan akibat adanya susut pengeringan pada beton. Gesekan 
antara tulangan baja dan beton juga meningkatkan tahanan terhadap gelincir. Efek total ini disebut sebagai lekatan (bond). Kuat lekat tulangan dengan beton tergantung pada faktor-faktor utama sebagai berikut:

a. lekatan antara beton dan tulangan baja

b. efek gripping (memegang) sebagai akibat dari susut pengeringan beton di sekeliling tulangan

c. tahanan gesekan terhadap gelincir dan saling mengunci pada saat tulangan mengalami tegangan tarik

d. efek kualitas beton (kekuatan tarik dan tekannya)

e. efek penjangkaran ujung tulangan

f. diameter, bentuk dan jarak tulangan.

Berdasarkan SKSNI T-15-1991-03 panjang penyaluran dasar $\left(l_{d b}\right)$ tulangan baja tarik D36 atau lebih kecil dapat dihitung dengan Persamaan 1. berikut ini.

$$
l_{d b}=\frac{0,02 \cdot A_{b} \cdot f_{y}}{\sqrt{f^{\prime}{ }_{C}}} \geq 0,06 \cdot \mathrm{d}_{\mathrm{b}} \cdot \mathrm{f}_{\mathrm{y}}
$$

dengan:

$$
\begin{aligned}
& l_{d b}=\text { panjang penyaluran dasar }(\mathrm{mm}) \\
& \mathrm{d}_{\mathrm{b}} \quad=\text { diameter nominal batang tulangan baja }(\mathrm{mm}) \\
& \mathrm{A}_{\mathrm{b}} \quad=\text { luas penampang batang tulangan baja }\left(\mathrm{mm}^{2}\right) \\
& \mathrm{f}_{\mathrm{y}} \quad=\text { tegangan luluh baja (MPa) } \\
& \mathrm{f}_{\mathrm{c}} \quad=\text { kuat tekan beton (MPa) }
\end{aligned}
$$

Untuk mendapatkan panjang penyaluran $\left(l_{d}\right)$ yang diperlukan, panjang penyaluran dasar $\left(l_{d b}\right)$ dikalikan dengan faktor modifikasi sesuai dengan peruntukannya. Dalam segala hal panjang penyaluran $l_{d}$ tidak boleh kurang dari $300 \mathrm{~mm}$.

Ahmed dkk (2007) melakukan penelitian pengaruh panjang penyaluran terhadap 24 sampel beton mutu tinggi dan beton normal. Hasil penelitian ini menunjukkan bahwa dengan menambah panjang penyaluran dari $5 \mathrm{~d}_{\mathrm{b}}$ ke $10 \mathrm{~d}_{\mathrm{b}}$ kekuatan lekat bertambah baik untuk beton mutu tinggi maupun beton normal.

Karena mudah dalam pembuatan dan sederhana dalam pengujian maka pull out test banyak dipakai oleh para peneliti untuk mengevaluasi lekatan tulangan dengan beton. Pada pull out test tulangan ditarik dari beton sehingga beton di sekelilingnya mengalami tekan. Perilaku lekatan yang sebenarnya terjadi pada balok beton bertulang tidak seperti 
pada pull out test, tulangan dan beton di sekelilingnya keduanya mengalami tarik (Elagroudy, 2003).

Ada dua macam mekanisme kegagalan pada pull out test. Jenis kegagalan yang pertama adalah terbelahnya penutup beton dan jenis kegagalan yang kedua adalah tercabutnya tulangan. Ada beberapa parameter yang mengakibatkan kegagalan diantaranya adalah: jenis beban, besar beban, ketebalan penutup beton, diameter tulangan, kekangan terhadap tulangan, dan bentuk tulangan (Alavi-Fard dan Marzouk, 2004).

Gaya-gaya interaksi antara tulangan berprofil dan beton sekeliling dapat dilihat pada Gambar 1. berikut ini (Wang, 1993).

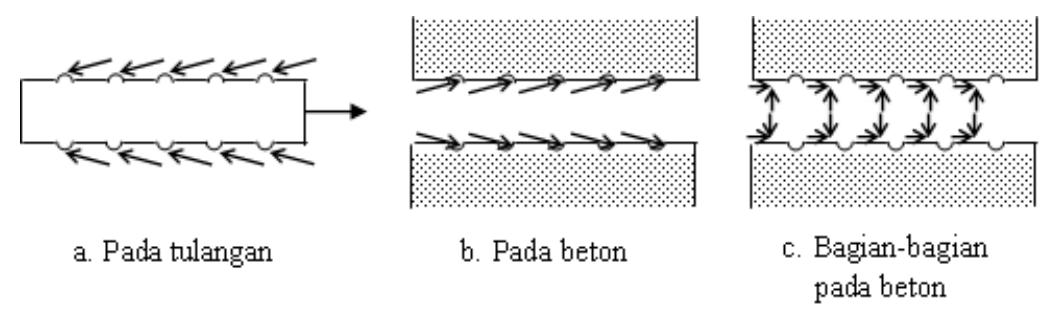

\section{Gambar 1. Gaya-gaya diantara tulangan dan beton}

\section{CARA PENELITIAN}

\subsection{Benda Uji}

Benda uji yang digunakan pada penelitian ini terdiri dari benda uji silinder beton untuk pengujian kuat tekan, benda uji kuat tarik baja, dan benda uji kuat lekat. Benda uji kuat lekat (pull out test) berbentuk silinder dengan diameter $15 \mathrm{~cm}$ dan tinggi $30 \mathrm{~cm}$. Pada bagian tengah silinder ditanam tulangan ulir berdiameter 16,4 mm dengan panjang penyaluran tulangan $\left(l_{d}\right)$ dibuat bervariasi seperti pada Tabel 1.

Tabel 1. Benda uji kuat lekat

\begin{tabular}{cccccc}
\hline No & $\begin{array}{c}\text { Diameter } \\
\text { tulangan, } d_{b} \\
(\mathrm{~mm})\end{array}$ & $\begin{array}{c}\text { Panjang } \\
\text { Penyaluran, } l_{d} \\
(\mathrm{~mm})\end{array}$ & $\begin{array}{c}\text { Selimut } \\
\text { beton, } c \\
(\mathrm{~mm})\end{array}$ & $c / d_{b}$ & $l_{d} / d_{b}$ \\
\hline 1 & 16,4 & 50 & 66,8 & 4,07 & 3,05 \\
\hline 2 & 16,4 & 100 & 66,8 & 4,07 & 6,10 \\
\hline 3 & 16,4 & 150 & 66,8 & 4,07 & 9,15 \\
\hline 4 & 16,4 & 200 & 66,8 & 4,07 & 12,20 \\
\hline 5 & 16,4 & 250 & 66,8 & 4,07 & 15,24 \\
\hline 6 & 16,4 & 300 & 66,8 & 4,07 & 18,29 \\
\hline
\end{tabular}




\subsection{Pengujian Kuat Lekat}
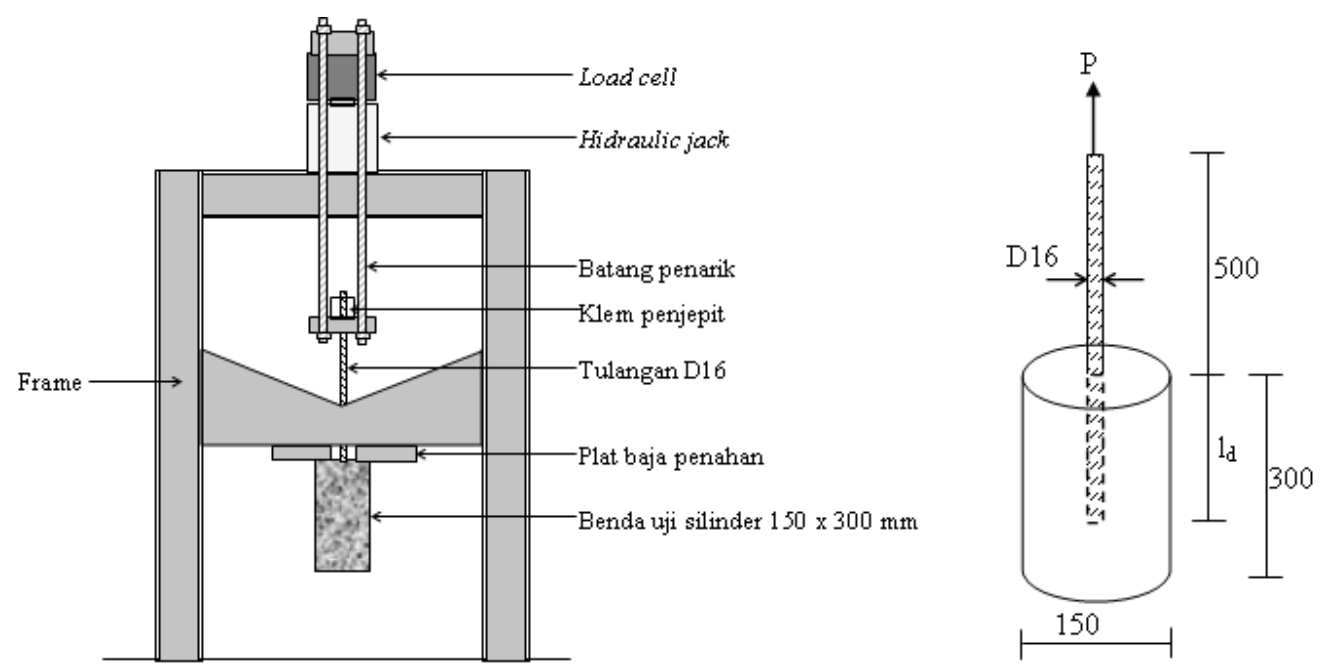

Gambar 2. Benda uji dan pengujian kuat lekat

Pengujian kuat lekat dilakukan dengan cara menempatkan silinder beton pada loading frame yang dilengkapi dengan hydraulic jack dan load cells, dan batang tulangan yang tertanam pada silinder ditarik sampai tercabut. Hasil pengujian berupa data beban maksimum. Untuk lebih jelasnya pengujian kuat lekat ini dapat dilihat pada Gambar 2.

\section{HASIL DAN PEMBAHASAN}

\subsection{Kuat Tekan Beton}

Hasil pengujian kuat tekan 6 buah silinder beton adalah seperti pada Tabel 2 .

Tabel 2. Kuat tekan beton

\begin{tabular}{|c|c|c|c|c|}
\hline $\begin{array}{c}\text { Benda } \\
\text { Uji }\end{array}$ & $\begin{array}{c}\text { Gaya } \\
\text { tekan }(\mathrm{N})\end{array}$ & $\begin{array}{l}\text { Diameter } \\
\text { (mm) }\end{array}$ & $\begin{array}{l}\text { Kuat tekan } \\
\text { (MPa) }\end{array}$ & $\begin{array}{c}\text { Tegangan } \\
\text { rata-rata } \\
(\mathrm{MPa})\end{array}$ \\
\hline I & 480000 & 150 & 27,16 & \multirow{6}{*}{27,63} \\
\hline II & 520000 & 150 & 29,43 & \\
\hline III & 480000 & 150 & 27,16 & \\
\hline IV & 400000 & 150 & 22,64 & \\
\hline $\mathrm{V}$ & 570000 & 150 & 32,26 & \\
\hline VI & 480000 & 150 & 27,16 & \\
\hline
\end{tabular}

Dari Tabel 2. dapat dilihat bahwa kuat tekan beton rata-rata sebesar 27,63 MPa. Beton ini termasuk beton normal sebab kuat tekannya berada antara 15 - $40 \mathrm{MPa}$. 


\subsection{Kuat Tarik Baja}

Hasil pengujian 3 buah benda uji tarik baja D16 adalah seperti pada Tabel 3.

Tabel 3. Pengujian tarik baja

\begin{tabular}{ccccc}
\hline $\begin{array}{c}\text { Benda } \\
\text { Uji }\end{array}$ & $\begin{array}{c}\text { Diameter } \\
\text { pengujian } \\
(\mathrm{mm})\end{array}$ & $\begin{array}{c}\text { Gaya tarik } \\
(\mathrm{kN})\end{array}$ & $\begin{array}{c}\text { Tegangan } \\
\text { luluh } \\
(\mathrm{MPa})\end{array}$ & $\begin{array}{c}\text { Tegangan luluh } \\
\text { rata-rata } \\
(\mathrm{MPa})\end{array}$ \\
\hline I & 11,82 & 53,5 & 487,56 & \multirow{2}{*}{483,66} \\
\hline II & 11,86 & 53,0 & 479,75 & \\
\hline
\end{tabular}

Dari Tabel 3. dapat dilihat bahwa tegangan luluh baja rata-rata sebesar 483,66 MPa.

\subsection{Kuat Cabut}

Hasil pengujian kuat cabut tulangan dengan berbagai variasi panjang penyaluran $\left(l_{d}\right)$ seperti pada Tabel 4. dan Gambar 3. berikut ini. Dari Tabel 4. dan Gambar 3. dapat dilihat bahwa peningkatan panjang penyaluran dari 50, 100, 150, 200, 250, hingga 300 mm meningkatan kemampuan benda uji untuk mendukung gaya cabut. Peningkatan kuat cabut untuk panjang penyaluran dari $50 \mathrm{~mm}$ sampai $200 \mathrm{~mm}$ hampir mendekati linear, dan kegagalan yang terjadi berupa tercabutnya tulangan dan silinder beton masih utuh. Pada panjang penyaluran 250 dan 300 mm peningkatan kuat cabut sudah tidak linear lagi karena pada kedua panjang penyaluran ini tulangan tercabut dan silinder beton terbelah. Untuk lebih jelasnya kegagalan yang terjadi pada benda uji dapat dilihat pada Gambar 4. dan 5.

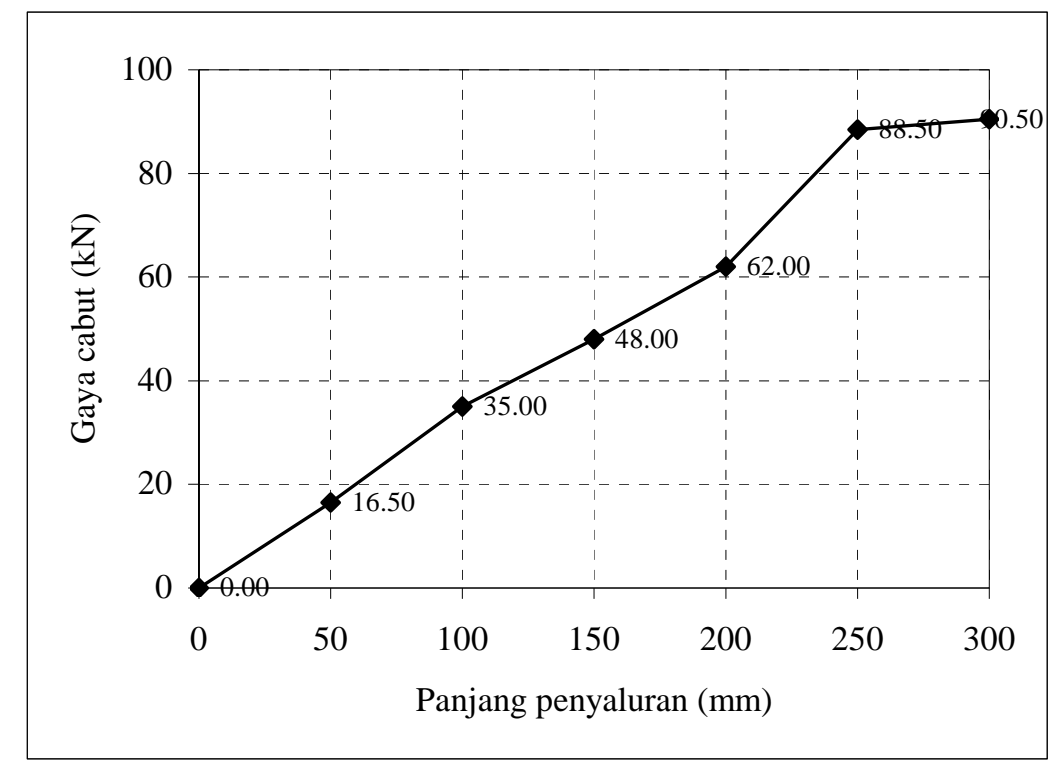

Gambar 3. Perbandingan kuat cabut tulangan 
Tabel 4. Pengujian kuat lekat tulangan

\begin{tabular}{|c|c|c|c|c|}
\hline No. & $\begin{array}{c}\text { Benda } \\
\text { Uji }\end{array}$ & $\begin{array}{c}\text { Panjang } \\
\text { penyaluran, } l_{d} \\
(\mathrm{~mm})\end{array}$ & $\begin{array}{c}\text { Gaya cabut, } \mathrm{P} \\
(\mathrm{kN})\end{array}$ & $\begin{array}{c}\text { Gaya cabut } \\
\text { rata-rata } \\
(\mathrm{kN})\end{array}$ \\
\hline 1 & A & \multirow{2}{*}{50} & 14 & \multirow{2}{*}{16,50} \\
\hline 2 & B & & 19 & \\
\hline 3 & A & \multirow{2}{*}{100} & 38 & \multirow{2}{*}{35,00} \\
\hline 4 & B & & 32 & \\
\hline 5 & A & \multirow{2}{*}{150} & 51 & \multirow{2}{*}{48,00} \\
\hline 6 & B & & 45 & \\
\hline 7 & A & \multirow{2}{*}{200} & 65 & \multirow{2}{*}{62,00} \\
\hline 8 & B & & 59 & \\
\hline 9 & A & \multirow{2}{*}{250} & 93 & \multirow{2}{*}{88,50} \\
\hline 10 & B & & 84 & \\
\hline 11 & A & \multirow{2}{*}{300} & 88 & \multirow{2}{*}{90,50} \\
\hline 12 & B & & 93 & \\
\hline
\end{tabular}

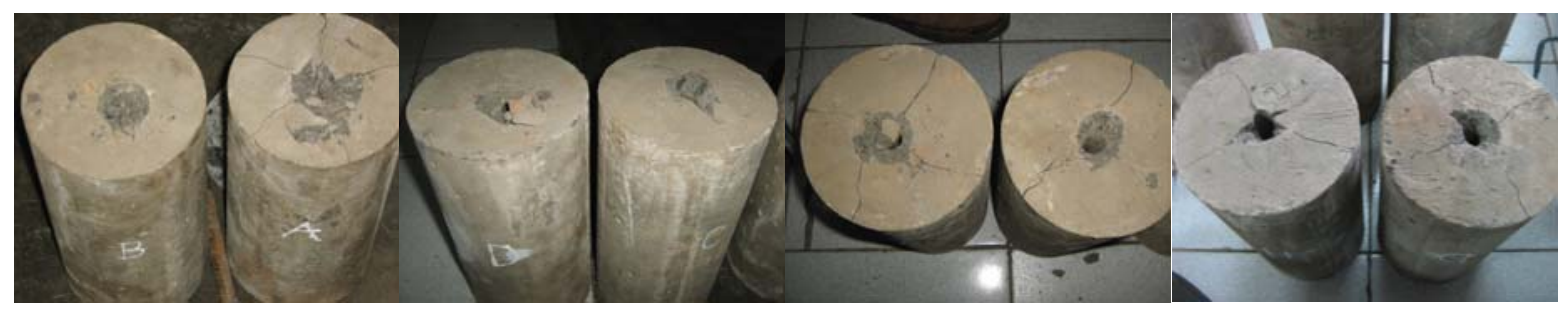

Gambar 4. Kegagalan panjang penjangkaran 50, 100, $150 \mathrm{~mm}$, dan $200 \mathrm{~mm}$ (tulangan tercabut, beton utuh)

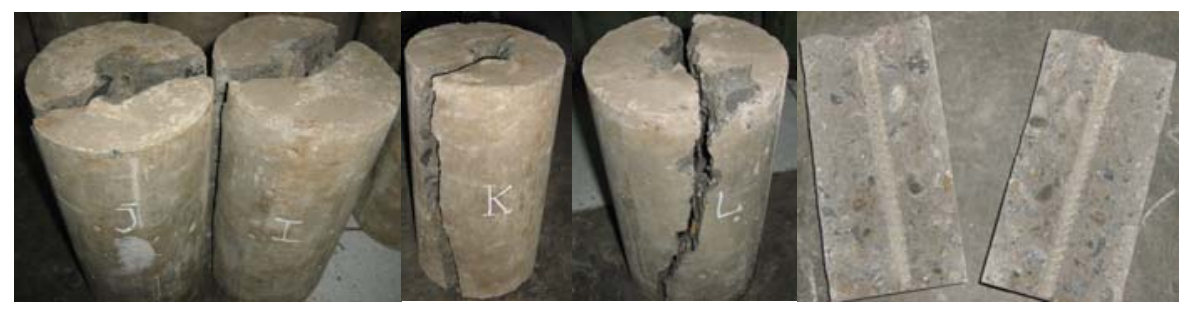

Gambar 5. Kegagalan panjang penjangkaran 250 dan $300 \mathrm{~mm}$ (tulangan tercabut, beton terbelah)

Untuk mengetahui kondisi tulangan sudah luluh atau belum akibat beban cabut untuk masing-masing panjang penyaluran dapat dilihat dari Tabel 5. 
Tabel 5. Tegangan yang terjadi pada tulangan berdasarkan gaya cabut

\begin{tabular}{ccccc}
\hline $\begin{array}{c}\text { Panjang } \\
\text { penyaluran, } \mathrm{l}_{\mathrm{d}} \\
(\mathrm{mm})\end{array}$ & $\begin{array}{c}\text { Gaya cabut } \\
(\mathrm{kN})\end{array}$ & $\begin{array}{c}\text { Diameter } \\
\text { tulangan } \\
(\mathrm{mm})\end{array}$ & $\begin{array}{c}\text { Tegangan } \\
(\mathrm{MPa})\end{array}$ & Keterangan \\
\hline 50 & 16,50 & 16,40 & 78,11 & tulangan belum luluh \\
\hline 100 & 35,00 & 16,40 & 165,69 & tulangan belum luluh \\
\hline 150 & 48,00 & 16,40 & 227,23 & tulangan belum luluh \\
\hline 200 & 62,00 & 16,40 & 293,50 & tulangan belum luluh \\
\hline 250 & 88,50 & 16,40 & 418,95 & tulangan belum luluh \\
\hline 300 & 90,50 & 16,40 & 428,42 & tulangan belum luluh \\
\hline
\end{tabular}

Berdasarkan Tabel 5. dapat disimpulkan bahwa baja tulangan pada pengujian cabut (pull out test) untuk setiap panjang penyaluran belum mencapai luluh karena tegangan yang terjadi masih di bawah tegangan luluh baja yang besarnya 483,66 MPa seperti pada Tabel 3.

Berdasarkan SK SNI T-15-1991-03 panjang penyaluran dasar $\left(l_{d b}\right)$ berdasarkan Persamaan 1. didapat sebesar 475,92 mm, atau dalam segala hal panjang penyaluran $\left(l_{d}\right)$ tidak boleh kurang dari 300 mm. Dari Tabel 5. dapat dilihat bahwa peningkatan panjang penyaluran dari $250 \mathrm{~mm}$ menjadi $300 \mathrm{~mm}$ tidak efektif karena tidak dapat untuk mengembangkan tegangan baja hingga mencapai tegangan luluh. Hal ini diakibatnya silinder beton pecah sehingga peningkatan tegangan yang terjadi pada tulangan hanya sedikit. Berdasarkan SNI 03-2847-2002, tebal selimut beton minimum untuk struktur yang tidak langsung berhubungan dengan cuaca atau tidak langsung berhubungan dengan tanah seperti balok dan kolom sebesar $40 \mathrm{~mm}$. Selimut beton yang digunakan pada penelitian ini sebesar 66,8 mm, jadi sudah memenuhi persyaratan. Pecahnya penutup beton diakibatkan oleh beton di sekeliling tulangan mengalami tekan, sehingga walaupun selimut beton yang tersedia sudah memenuhi persyaratan tapi masih terjadi kegagalan. Kondisi ini berbeda dengan perilaku lekatan yang sebenarnya terjadi pada balok beton bertulang yang tulangan dan betonnya keduanya mengalami tarik.

\section{KESIMPULAN DAN SARAN}

\subsection{Kesimpulan}

1. Peningkatan panjang penyaluran dari 50, 100, 150, 200, 250, hingga $300 \mathrm{~mm}$ meningkatan kemampuan benda uji untuk mendukung gaya cabut.

2. Kuat cabut meningkat dan berbanding lurus sampai panjang penyaluran tertentu.

3. Kegagalan pada uji cabut tulangan dapat berupa tulangan tercabut beton utuh atau tulangan tercabut beton terbelah. 


\subsection{Saran}

1. Perlu dilakukan penelitian pengaruh panjang penyaluran dengan benda uji berupa balok sehingga sesuai dengan kondisi nyata.

2. Pengukuran deformasi sebaiknya dilakukan juga pada pengujian pull out sehingga didapat beban cabut pada saat tulangan telah bergeser minimum 2,5 mm seperti yang diatur pada SNI 03-4809-1998.

\section{DAFTAR PUSTAKA}

1. Ahmed, K., Siddiqi, Z.A., dan Yousaf, M., 2007, Slippage of Steel in High and Normal Strength Concrete, Pak. J. Engg. \& Appl. Sci., Vol. 1, Pakistan. http://www.uet.edu.pk/export/sites/UETWebPortal/research/researchinfo/journal/v olume1/article5.pdf

2. Alavi-Fard, M., dan Marzouk, H., 2004, Bond of High Strength Concrete Under Monotonic Pull Out Loading, Faculty of Engineering and Applied Science, Memorial University of Newfoundland, St. John's, NF, Canada. http://www.engr.mun.ca/ hmarzouk/MCR\%20Marzouk\%20text.pdf

3. Dipohusodo, I., 1994, Struktur Beton Bertulang, PT, Gramedia Pustaka Utama, Jakarta.

4. Elagroudy, H., 2003, Bond Characteristics Of Micro-Composite Multistructural Formable Steel Used In Reinforced Concrete Structures, Master of Science Thesis, Civil Engineering, North Carolina State University, USA, http://www.lib.ncsu.edu/theses/available/etd-07252003213630/unrestricted/etd.pdf

5. Nawy, E.G., 1998, Beton Bertulang suatu Pendekatan Dasar, Cetakan II, PT Refika Aditama, Bandung.

6. SK SNI T-15-1991-03, 1991, Tata Cara Perhitungan Struktur Beton Untuk Bangunan Gedung, Yayasan LPMB, Departemen Pekerjaan Umum RI.

7. SNI 03-2847-2002, Tata Cara Perencanaan Struktur Beton Untuk Bangunan Gedung, Puslitbang Permukiman, Departemen Pekerjaan Umum.

8. SNI 03-4809-1998, Metode Pengujian Untuk Membandingkan Berbagai Beton Berdasarkan Kuat Lekat Yang Timbul Terhadap Tulangan, Puslitbang Permukiman, Departemen Pekerjaan Umum.

9. Wang, C.K. dan Salmon, C.G., 1993, Desain Beton Bertulang, Edisi Ke-4, Jilid 1, Erlangga, Jakarta. 